\title{
The Use of Geoinformtics in Site Selection for Suitable Landfill for Poultry Waste: A Case Study of Amo Farms, AWE AFIJIO, Oyo State
}

\author{
Onosemuode Christopher ${ }^{1}$, Abodurin Wasiu Adeyemi ${ }^{1}$
}

\begin{abstract}
${ }^{1}$ Department of Environmental Science, College of Sciences, Federal University of Petroleum Resources, Effurun
ABSTRACT: This study focused on selection of suitable landfill site for poultry waste in Amo farms Nigeria Limited Awe, Afijio Local Government. The data sets used for the study include; Satellite imagery (Landsat) and topographic maps of the study area. The layers created include those for roads, water bodies, farm sites and the slope map of the study area to determine the degree of slope. The various created layers were subjected to buffering, overlay and query operations using ArcGis 9.3 alongside the established criteria for poultry waste site selection. At the end of the analytical processes, search query was used to generate two most suitable sites of an area that is less than or equal to $20,000 \mathrm{~m}^{2}$ ( 2 hectares).
\end{abstract}

Keywords: Poultry, waste, Site, Geoinformatics, Selection

\section{INTRODUCTION}

Disposal sites in some developing countries Nigeria inclusive are usually not selected in line with established criteria aimed at safeguarding the environment and public health. Refuse dumps are sited indiscriminately without adequate hydrogeological and geotechnical considerations. Hence, there is always the possibility of contamination of groundwater sources in permeable substrate and unpleasant odour in the environment. This is particularly obvious in some of our towns and cities in Nigeria (Agunwanba et al, 1997, UNEP, 1996).

Although, Agricultural development all over the World has emerged as a mixed blessing while Agricultural Industries benefit a nation economically by providing jobs and other human needs useful in raising the living standard of the nation as a whole, a lot of havoc are also done on the environment and the nation in general (Ukpog, 2000; and Mc Graw-Hill, 1978).

Many Agricultural developing countries of the world especially African countries and Nigeria in particular are still having a swell time handling their byproducts. For instance, while farms are springing up in every nooks and cranny of Nigeria, little attention has been paid to the area of selecting the most suitable sites for their waste deposition. However, with the on-going increase in livestock farming there is need for both private and public authorities to build up efforts at managing the various wastes generated by these various agricultural set-ups. In order to do this, GIS plays a leading role in selecting suitable location for waste disposal sites based on its planning and operations that are highly dependent on spatial data. Generally speaking, GIS plays a key role in maintaining data; analyzing optimal locations for transfer station; planning routes for vehicles transporting waste from farm sites to landfill location and monitoring of the site. GIS does not only reduce time and cost of site selection, but also provide a future monitoring program of the site (Chain, 1971). Geographic information system (GIS), as a spatial decision support tools (Onosemuode et al, 2010 and Eastman et al. 1993), can be used to select the appropriate and best site for location for solid waste

The focus of this work is to suggest a suitable landfill site for Poultry waste using GIS. The need for this work stems from the need to plan for the Farm to avoid environmental hazard from its improper disposal of poultry waste around its environment as waste are dump indiscriminately. Therefore, a most suitable landfill site for dumping wastes has to be designed using GIS for effective sustainable healthy environment.

\section{STATEMENT OF PROBLEM}

This article is published under the terms of the Creative Commons Attribution License 4.0 Author(s) retain the copyright of this article. Publication rights with Alkhaer Publications.

Published at: http://www.ijsciences.com/pub/issue/2016-04/

DOI: 10.18483/ijSci.988; Online ISSN: 2305-3925; Print ISSN: 2410-4477 
One of the ways by which government encourages the Nigeria youth is to be able to generate selfincome through means of small scale business, so as to combat the economic situation of the Country. However, from such act it might become a big company that employs in hundreds and contribute to nation's development.

Amo Farms Nigeria Limited is situated at Awe Township under Afijio Local Government Area. It has various sites across Awe municipal. Poultry waste is generated from each of these sites on daily basis and disposed at least twice a week by transporting them to near or faraway places- on somebody else's land. Though this waste can serve as manure for farmers around the farm site but constitutes a threat to the environment because of indiscriminate disposal of this waste. The environment is polluted by the unpleasant odour emanating from the waste; it is usually washed down to a nearby Rivers/ Streams that are drinkable somewhere else. This act of indiscriminate dumping of the waste poses threat to the people's health. Going by this concept of improper waste disposal, the entire environment will suffer the consequence of it in near or far future to come if no appropriate measure of waste dump is devised to take care of the indiscriminate waste dump. In order to prevent more future hazards to the environment, a positive tool for proper waste management has been advocated hence this study.

\section{THE STUDY AREA}

The study area for the project is Amo farms Nigeria Limited, Awe, Afijio Local Government. Amo covers about 30-50 hectares of land in Awe while it lies within the geographic coordinates of latitude $07^{0} 49^{\prime}$ 39", longitude $03^{\circ} 57^{\prime} 30^{\prime \prime}$ and Latitude $07^{\circ} 48^{\prime} 43^{\prime \prime}$ longitude $03^{\circ} 58^{\prime} 44^{\prime \prime}$.

Afijio Local Government Area consists of ten (10) wards and it came into existence after the Federal Government carved it from Old Oyo Local Government Area in 1989. The Administrative headquaters of the Local Government is located at Jobele. It occupies a land area of 685.085 square kilometers with 2010 estimated population size of 152,193 using a growth rate of $3.2 \%$ from 2006 census figures. The population density of the area is 222 persons per square kilometer. It is bounded in the North by Oyo East Local Government Area, Akinyele Local Government Area in the South and Iseyin Local Government Area in the West. It also shares common boundary with Ejigbo and Iwo Local Government Areas in the East. The Yorubas mainly dominate Afijio Local Government Area (Fig.1). The indigenes are mostly farmers who had taken the advantage of vast Agricultural land that favours the cultivation of food crops such as maize, guinecorn, yam, cassava, cowpea, soya beans, fruits, tomatoes and cash crops such as groundnuts, cocoa, oil-palm, kolanuts, coffee, orange and citrus. The Local Government Area is a home for one of the State farm settlements - Ilora farm settlement. A number of tourists attraction centres located in the Local Government areas includes Ese Oloja Hill (Ilora), Ifaniyi Hill (Oke Isemi) Ilora, Obanikoro (Ilora), Erugun (Ilu-Aje), Sogidi Lake (Aawe) Igi Omo (Ilora), Odo Eegbe (Fiditi), Yemoja (Akinmorin), Kutanti Shrine (Aawe) Among others. 
The Use of Geoinformtics in Site Selection for Suitable Landfill for Poultry Waste: A Case Study of Amo Farms, AWE AFIJIO, Oyo State

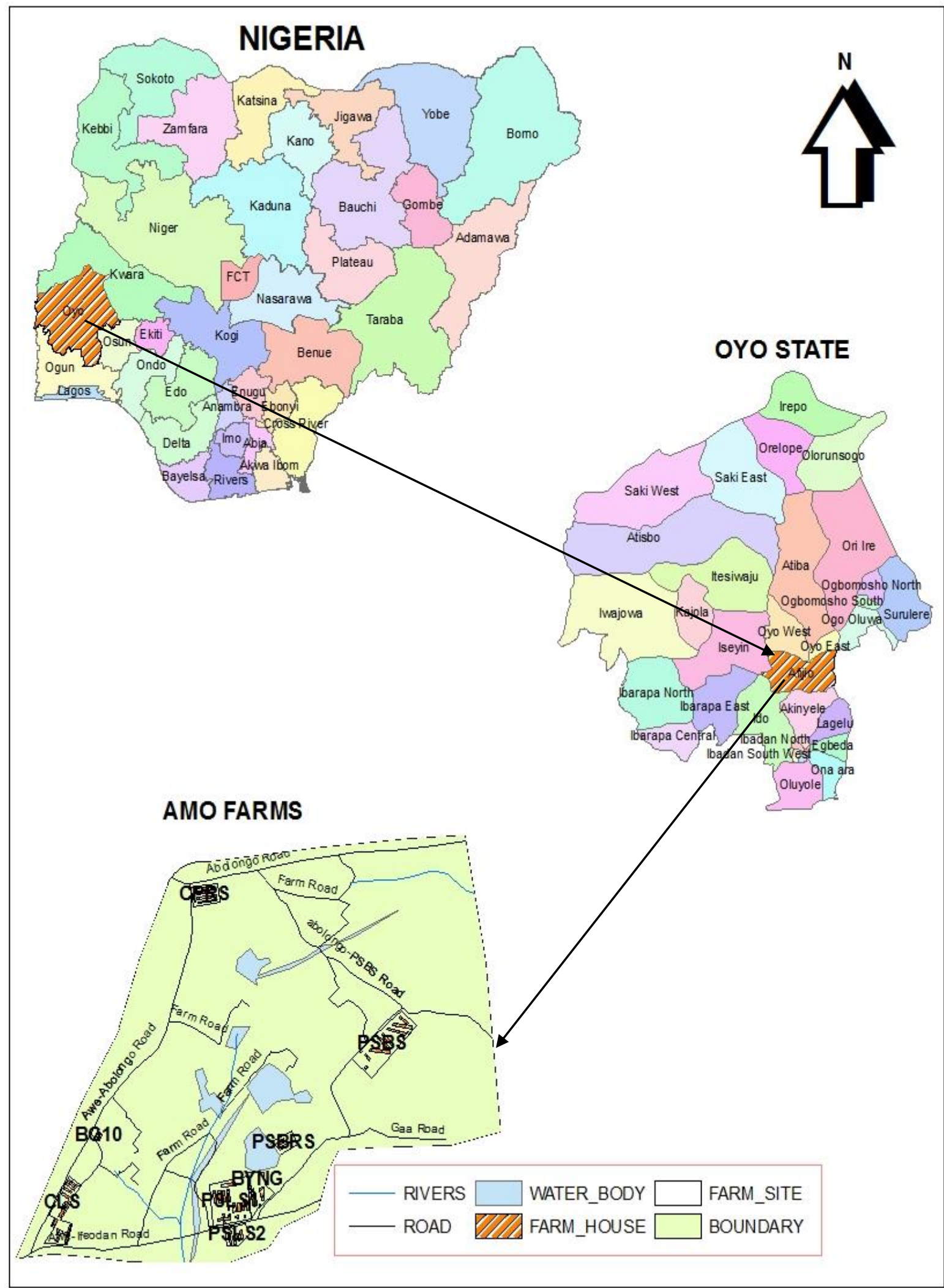

Fig. 1: Diagram of Study Area. 
The Use of Geoinformtics in Site Selection for Suitable Landfill for Poultry Waste: A Case Study of Amo Farms, AWE AFIJIO, Oyo State

\section{RESEARCH METHOD}

\section{Data Sources}

The sources of data used for this project were primary and secondary. The primary source of data is the use of GPS to generate coordinates for the poultry site for effective representation in ArcGis environment.

While the secondary sources include:

- Topographical Map of the study area at Scale 1:50000 from Federal Survey Lagos.
- Landsat Imagery of the study area .

\section{Cartographic Models}

Cartographic modeling is a specially designed map processing means, which can be used to handle analytical problems in geographic information processing. This is represented with cartographic model showing the sequence of operations, explicit assumptions and the relationship between the variables as shown in figure 2 .

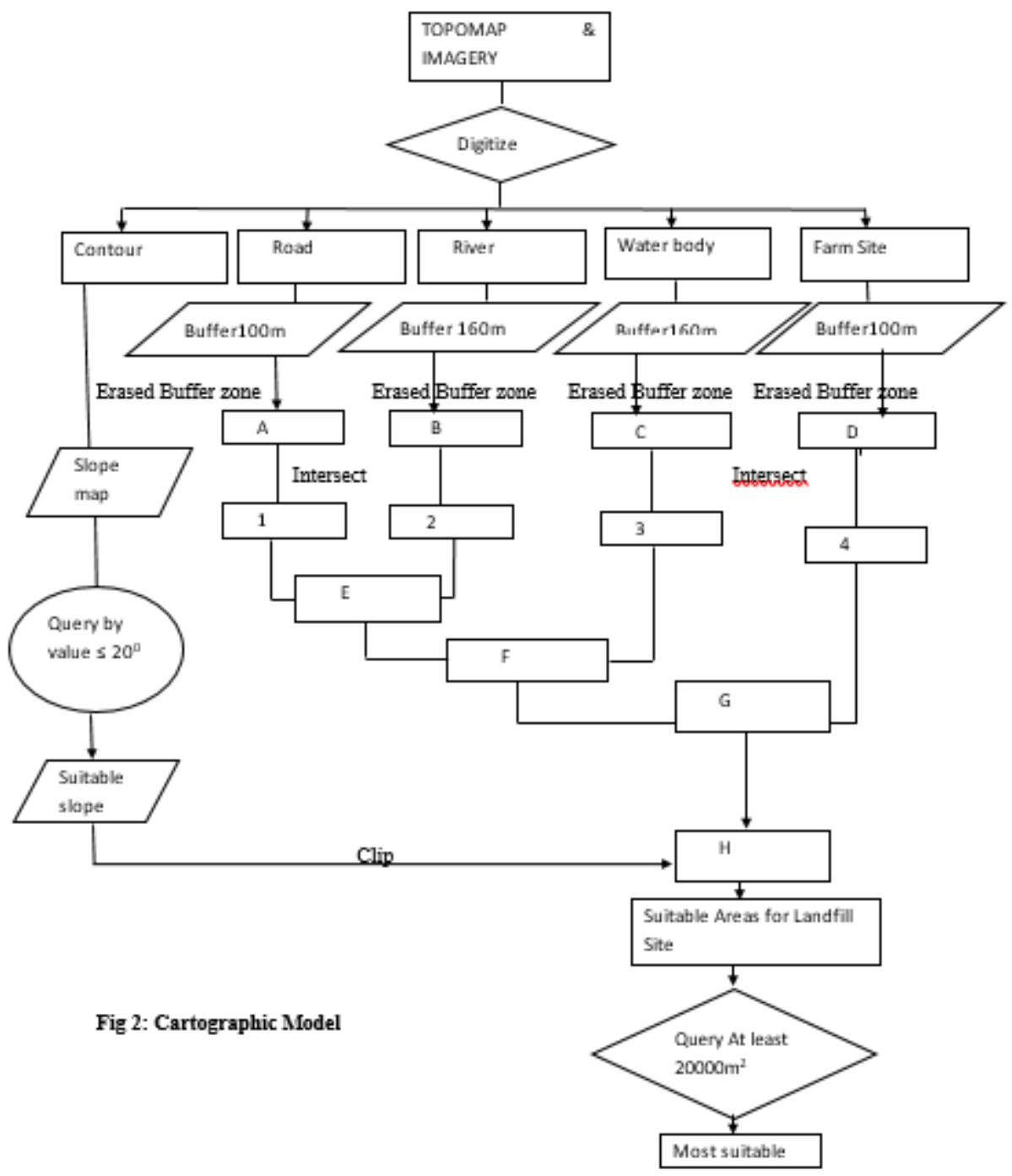

Fig 2: Cartographic Model 


\section{Data Analysis}

Having acquired the data, the following data processes aid analysis that was carried out.

- Scanning - The topographic map collected were scanned with the help of scanning Machine to make conversion easier while doing on-screen digitizing after georeferencing.

- Geo-referencing - This was done to bring the scanned map to their true earth location or position using an acceptable referencing system (e.g UTM)

- Digital Database Creation - This was done to store digital data relating to the size, location, easting and northing of the study area.

- DEM Generation - The Digital elevation model of the area was also generated from a series of contour lines $\mathrm{X}, \mathrm{Y}$ and $\mathrm{Z}$ coordinates obtained from the scanned map and stored in the database.

\section{PRESENTATION AND DISCUSSION OF RESULTS}

\section{CONSTRAINTS AND CRITERIA FOR LANDFILL SITE SELECTION}

The basic criteria for landfill selection for poultry waste used in this study are as follows:

i. The site must be at least $100 \mathrm{~m}$ away from an existing road

ii. Site must be at least $160 \mathrm{~m}$ away from an existing River iii. The site must be $160 \mathrm{~m}$ away from water body

iv. Site must be $150 \mathrm{~m}$ away from an existing Farm site.

v. The landfill site should be located on a terrain with slope not more than 20 degree, to prevent erosion and to facilitate easy accessibility.

vi. The landfill site should cover at least an area of $20,000 \mathrm{~m}^{2}$ ( 2 hectares)

Source: Environmental Protection Agency (2006)-Manual on Site Selection.

In order to arrive at the most suitable landfill site for poultry waste in the study area the following analysis were performed using ArcGis 9.3:

- Buffering

- Overlay

- Database extraction (Query)

\section{ANALYSIS OF RESULTS}

\section{Buffering Operation}

Buffering is a process of generating a zone of influence usually of specified width around a map features

In this work, buffering operation was used to buffer Road at $100 \mathrm{~m}, 160 \mathrm{~m}$ for River, $160 \mathrm{~m}$ for water body and $150 \mathrm{~m}$ for Farm site to satisfy the criteria for adequate distance. (See figures. 3, 4, 5 and 6 respectively). 


\section{MAP SHOWING BUFFERED ROAD OF STUDY AREA}
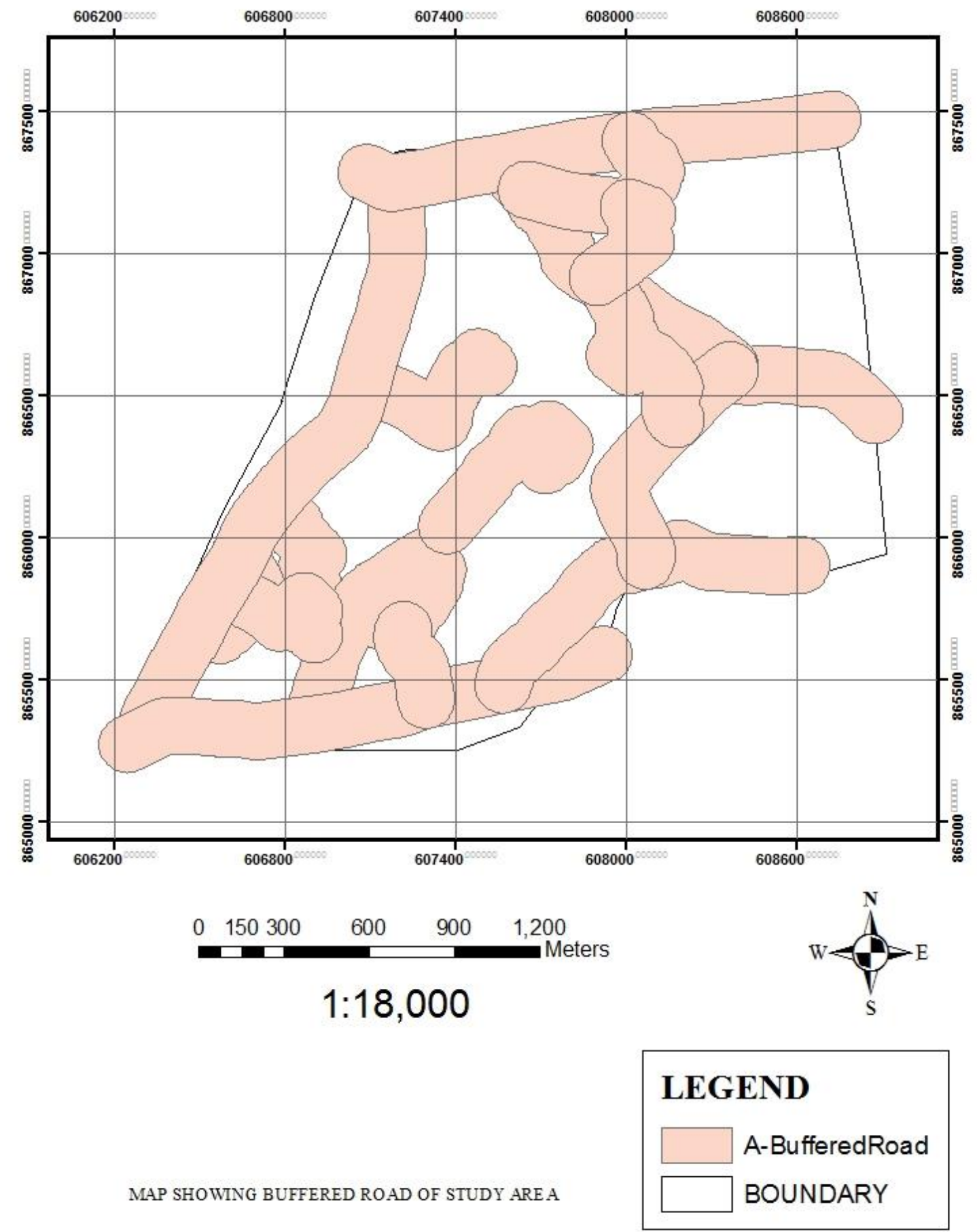

Fig. 3: Map of Study Area Showing Road buffered by 100m 


\section{MAP SHOWING BUFFERED RIVER OF STUDY AREA}
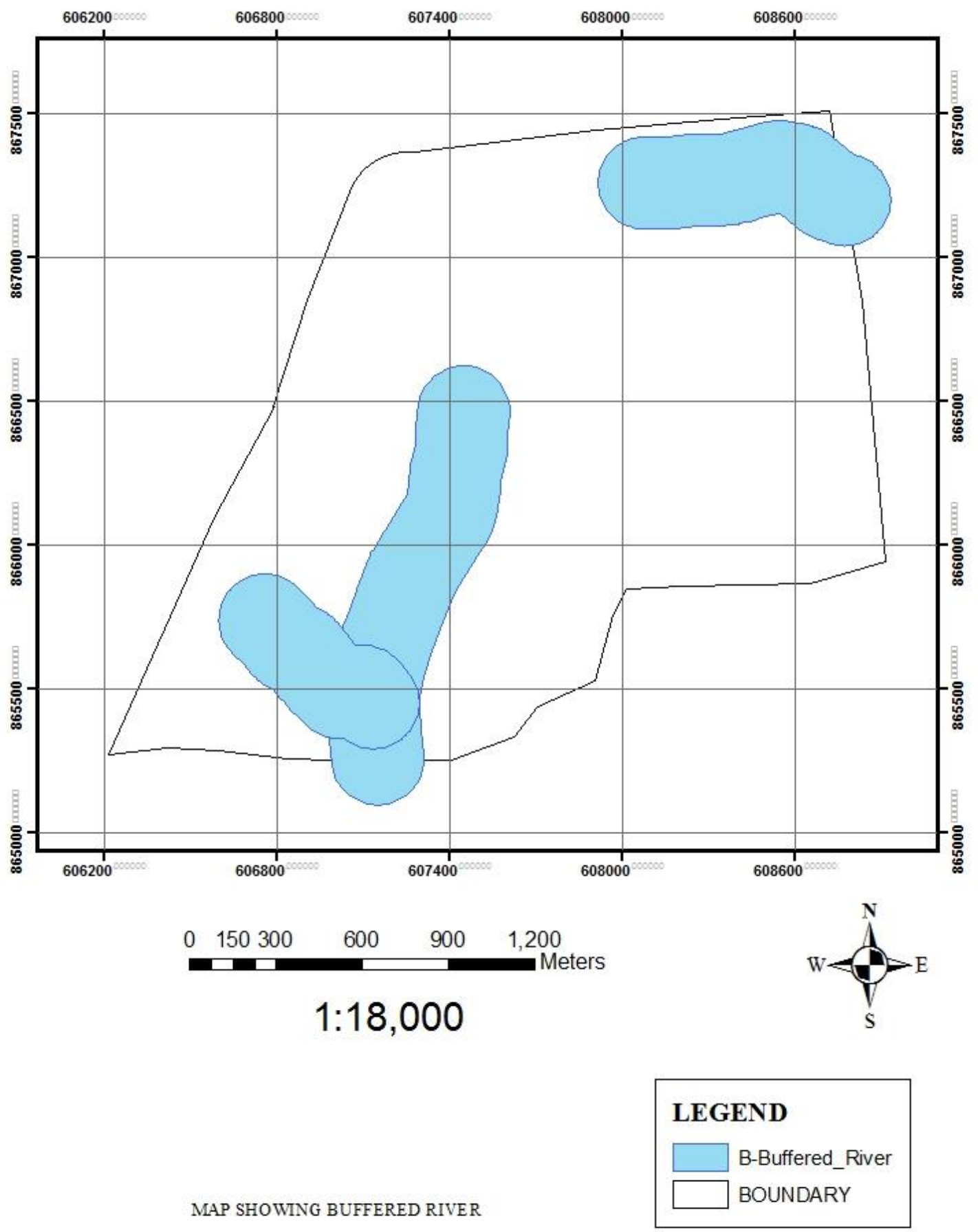

Fig. 4: Map of study Area Showing River buffered by $160 \mathrm{~m}$ 


\section{MAP SHOWING BUFFERED WATERBODY OF STUDY AREA}

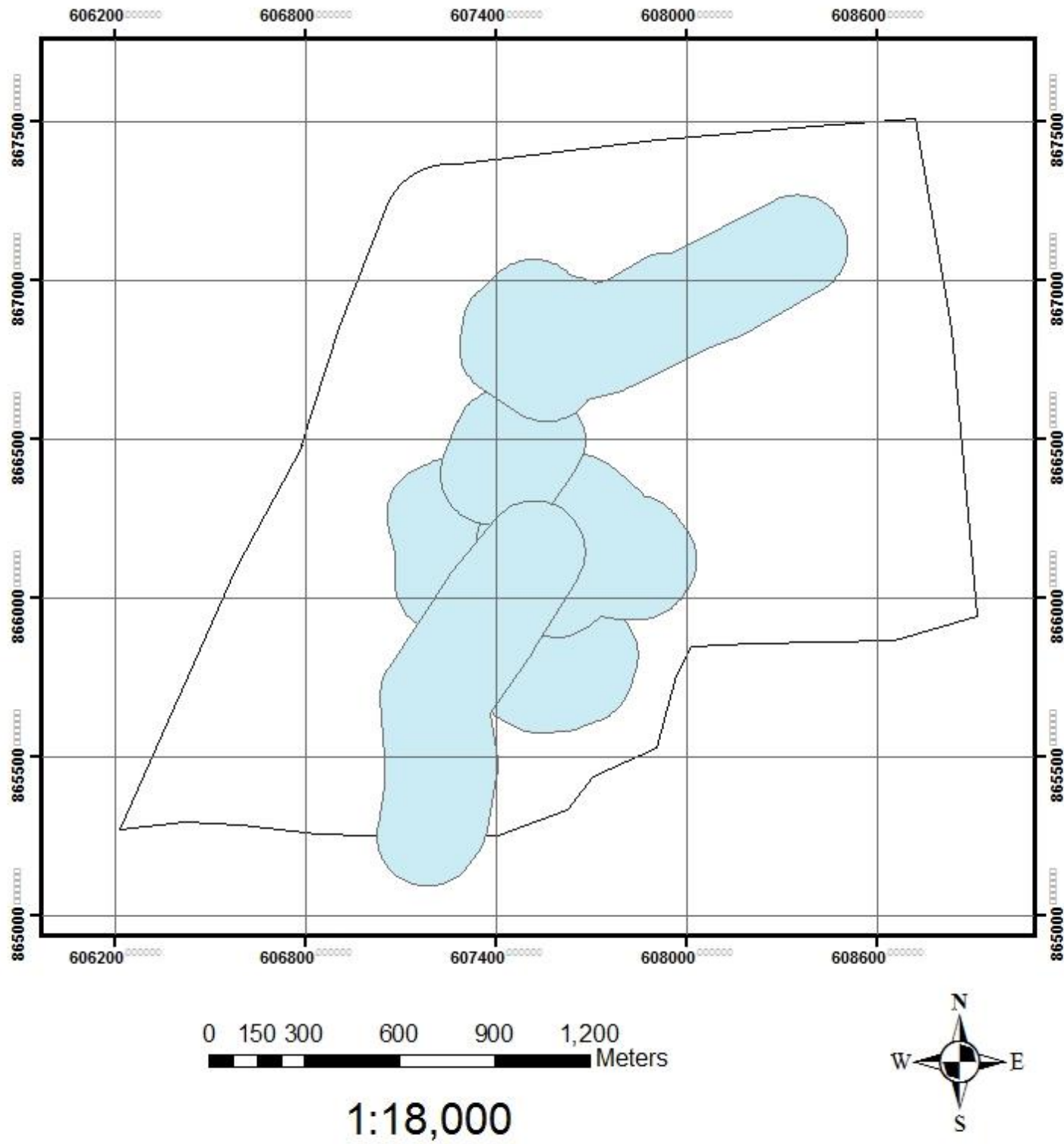

MAP SHOWING BUFFERED WATERBODY BY $160 \mathrm{M}$

\section{LEGEND}

C-Buffered_Waterbody BOUNDARY

Fig. 5: Map of study Area Showing Water Body buffered by $160 \mathrm{~m}$ 


\section{MAP SHOWING BUFFERED FARMSITE}

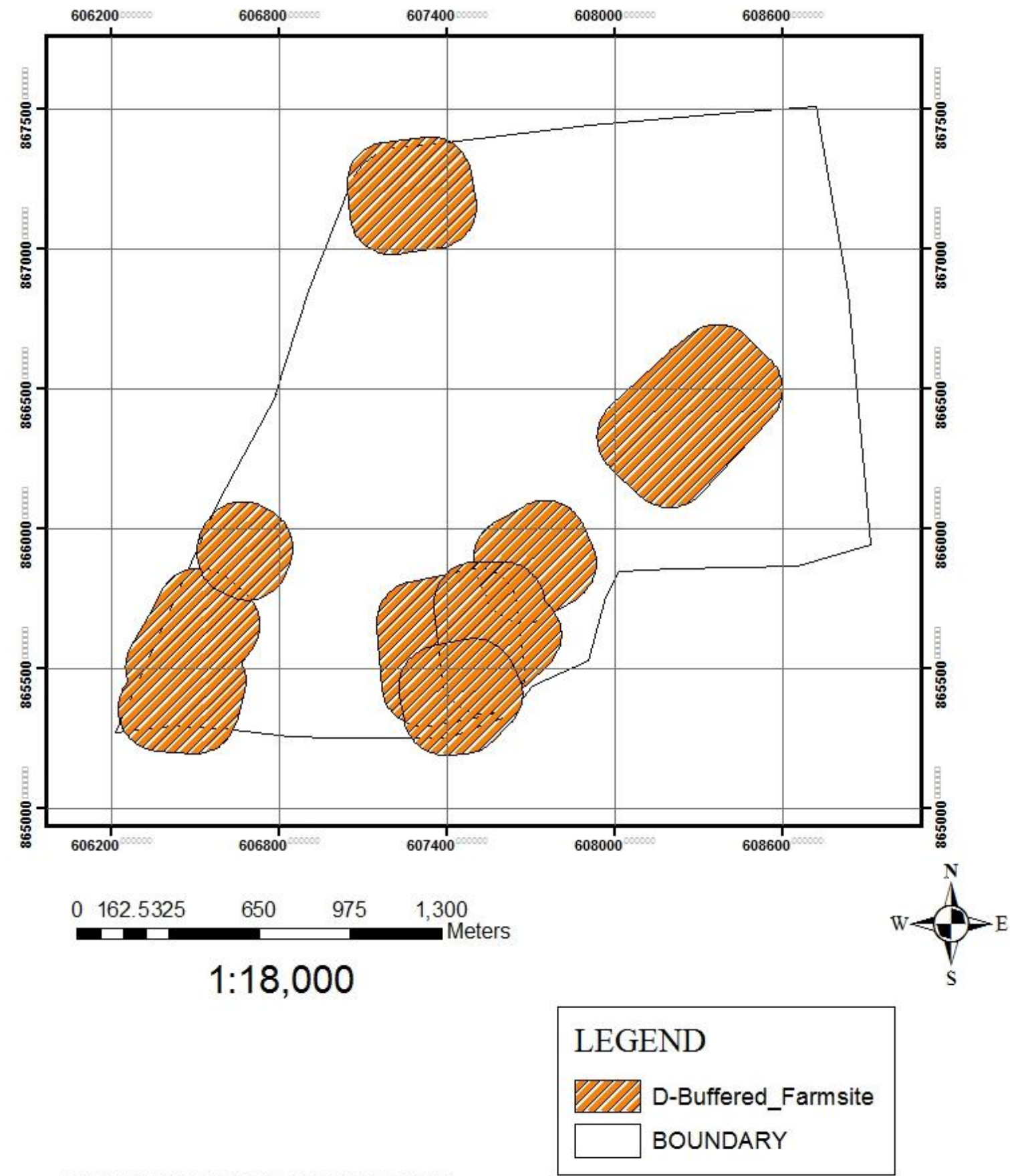

MAP SHOWING BUFFERED FARMSITE BY $150 \mathrm{M}$

Fig. 6: Map of Study Area Showing Farm Site buffered by 150m 
The Use of Geoinformtics in Site Selection for Suitable Landfill for Poultry Waste: A Case Study of Amo Farms, AWE AFIJIO, Oyo State

\section{OVERLAY OPERATION}

Overlay operation involves bringing two input data layers together to form a new layer. The principle of spatial overlay is to compare the characteristics of the same location in both data layers and to produce new characteristics for each location in the output data layer. Numerous overlay options exist, but erase, intersect and clip options were used. Erase option was used to remove buffered layers that involves buffered Road (A), Buffered River (B), Buffered water body (C) and Buffered Farm site (D) to generate suitable area 1,2,3 and 4 respectively. These 1-4 layers were then intersected as follow:

\section{First Intersection Layer Generation}

The first intersection layer generation was carried by intersecting suitable area 1 with the suitable area 2 to generate layer E ( fig. 7).

\section{MAP SHOWING INTERSECT OF SUITABLE AREA $1 \& 2$}

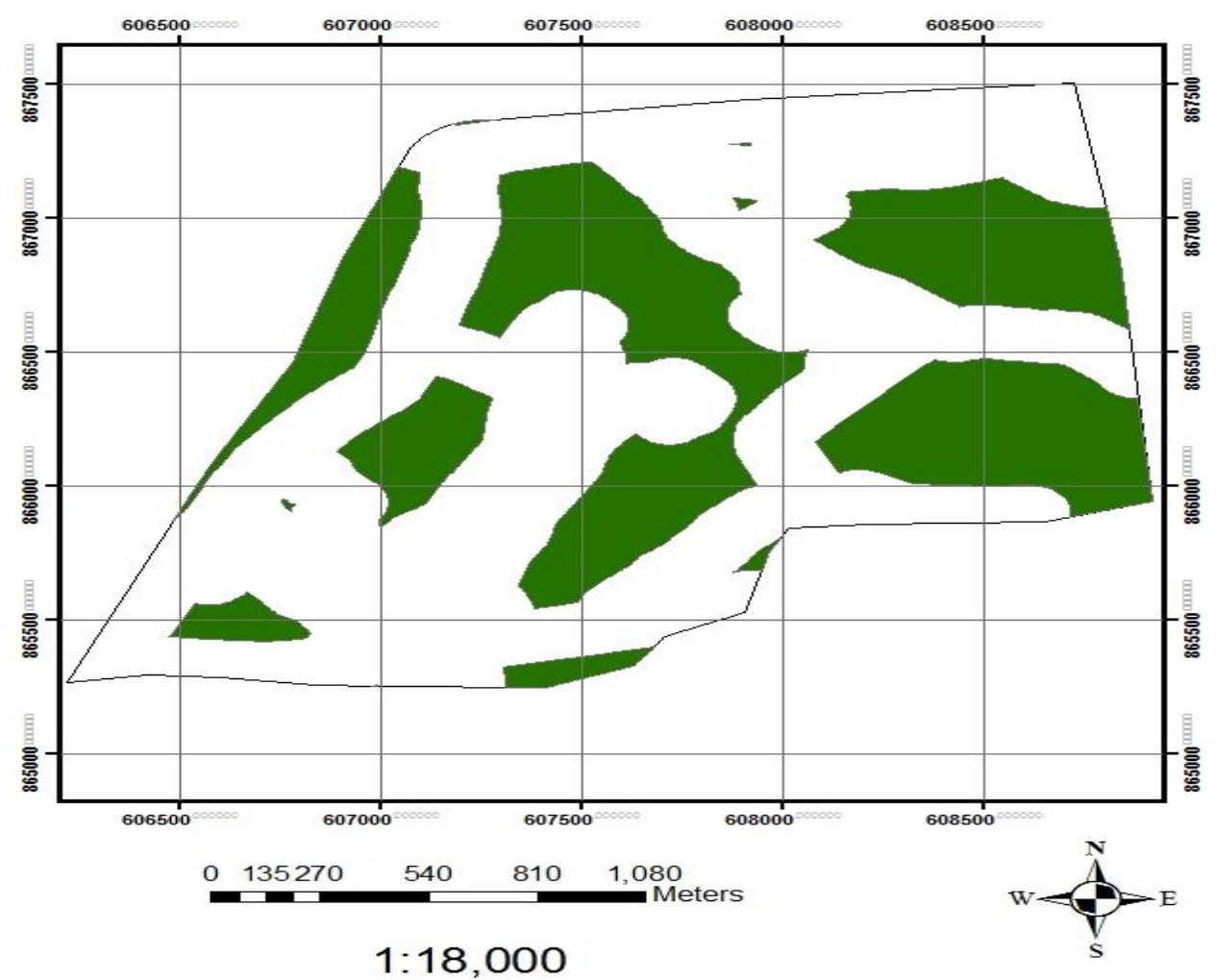

\section{LEGEND}

MAP SHOWING INTERSECT OF SUITABLE AREA $1 \& 2$ THAT GIVES E-LAYER

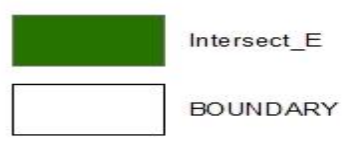

Fig. 7: Layer showing Intersect of Suitable Areas $1 \& 2$ that Generate Layer E 
The Use of Geoinformtics in Site Selection for Suitable Landfill for Poultry Waste: A Case Study of Amo Farms, AWE AFIJIO, Oyo State

\section{Second Intersection Layer Generation}

The second intersection layer generation was carried out by intersecting layer E with suitable area 3 to generate layer $\mathrm{F}$ as shown in figure 8 .

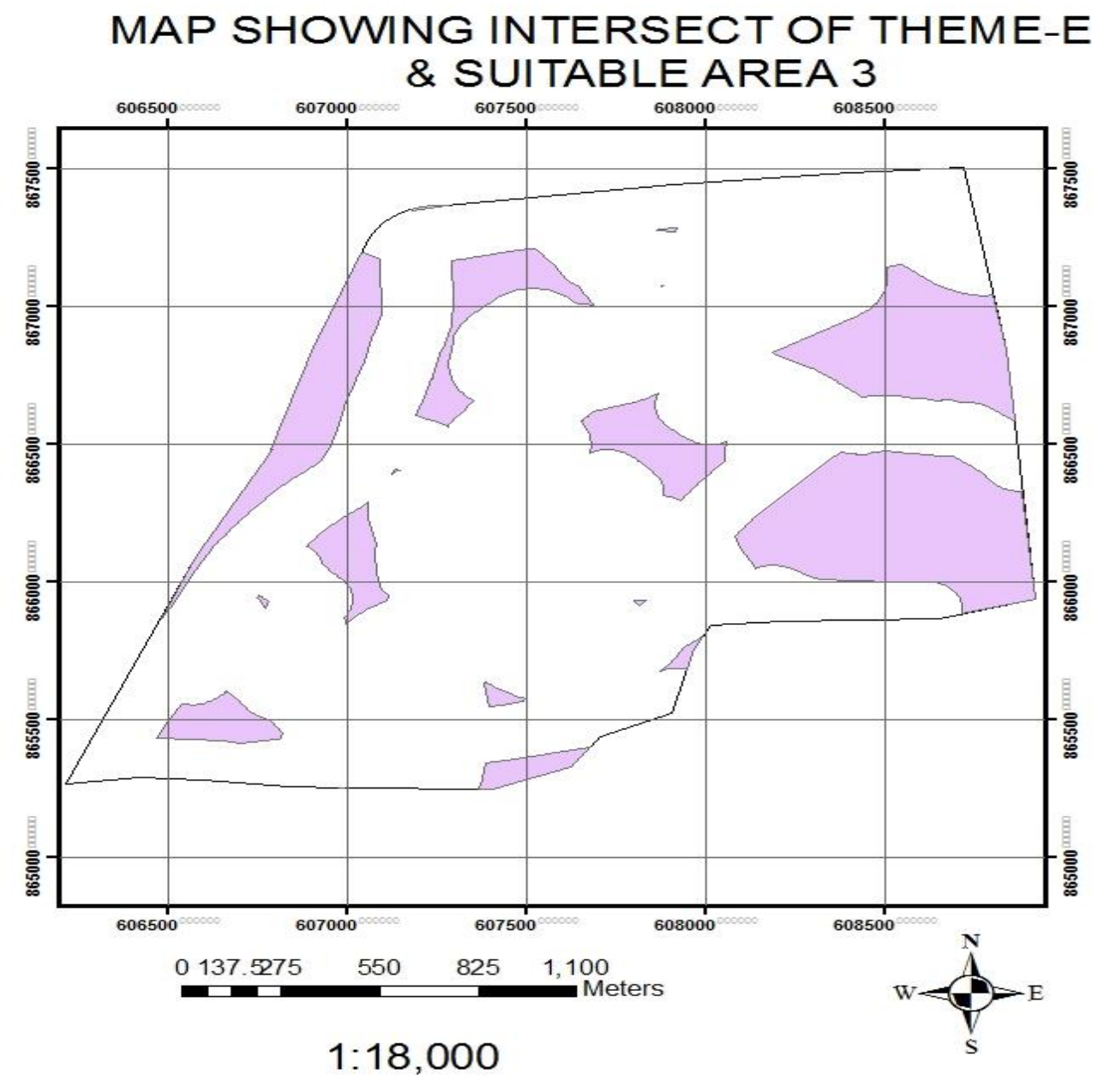

\section{LEGEND}

MAP SHOWING INTERSECT OF THEME-E\&SUITABLE AREA 3 THAT GIVES F-LAYER

Intersect_F

BOUNDARY

Fig. 8: Layer showing Intersect of Suitable Layers E\&3 to Generate Layer F 
The Use of Geoinformtics in Site Selection for Suitable Landfill for Poultry Waste: A Case Study of Amo Farms, AWE AFIJIO, Oyo State

\section{Third Intersection Layer Generation}

The third intersection layer generation was carried out by intersecting layer $\mathrm{F}$ with suitable area 4 to generate layer $\mathrm{G}$ which was later clipped with suitable slope to generate the most suitable area for landfill site as shown in figure. 9.

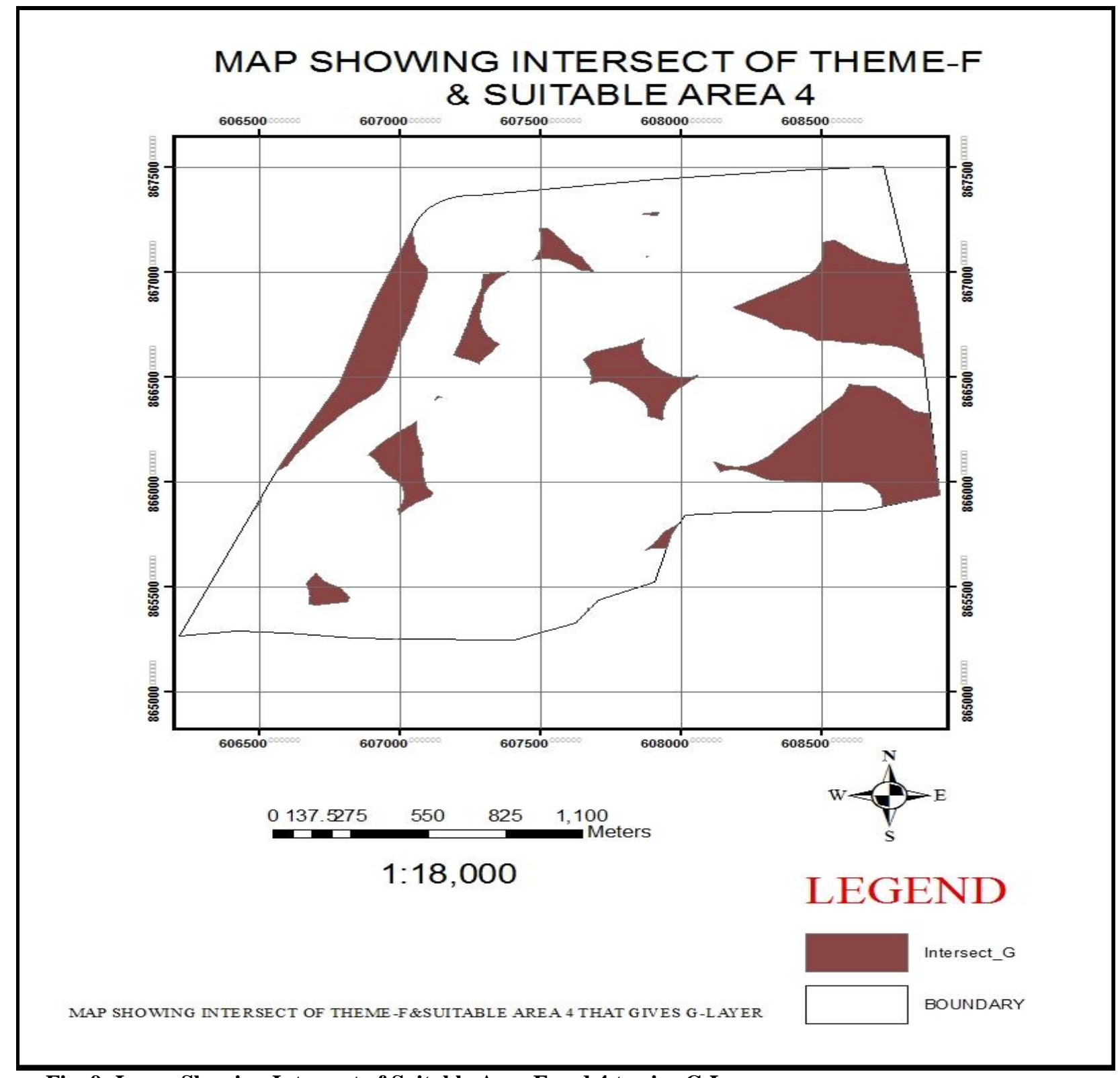

Fig. 9: Layer Showing Intersect of Suitable Area F and 4 to give G Layer

Extract (Clip option) was used to generate the suitable areas for landfill sites called layer $\mathrm{H}$ by clipping the slope layer (Fig. 10a) with layer $\mathrm{G}$ as shown in figure10b. 
The Use of Geoinformtics in Site Selection for Suitable Landfill for Poultry Waste: A Case Study of Amo Farms, AWE AFIJIO, Oyo State

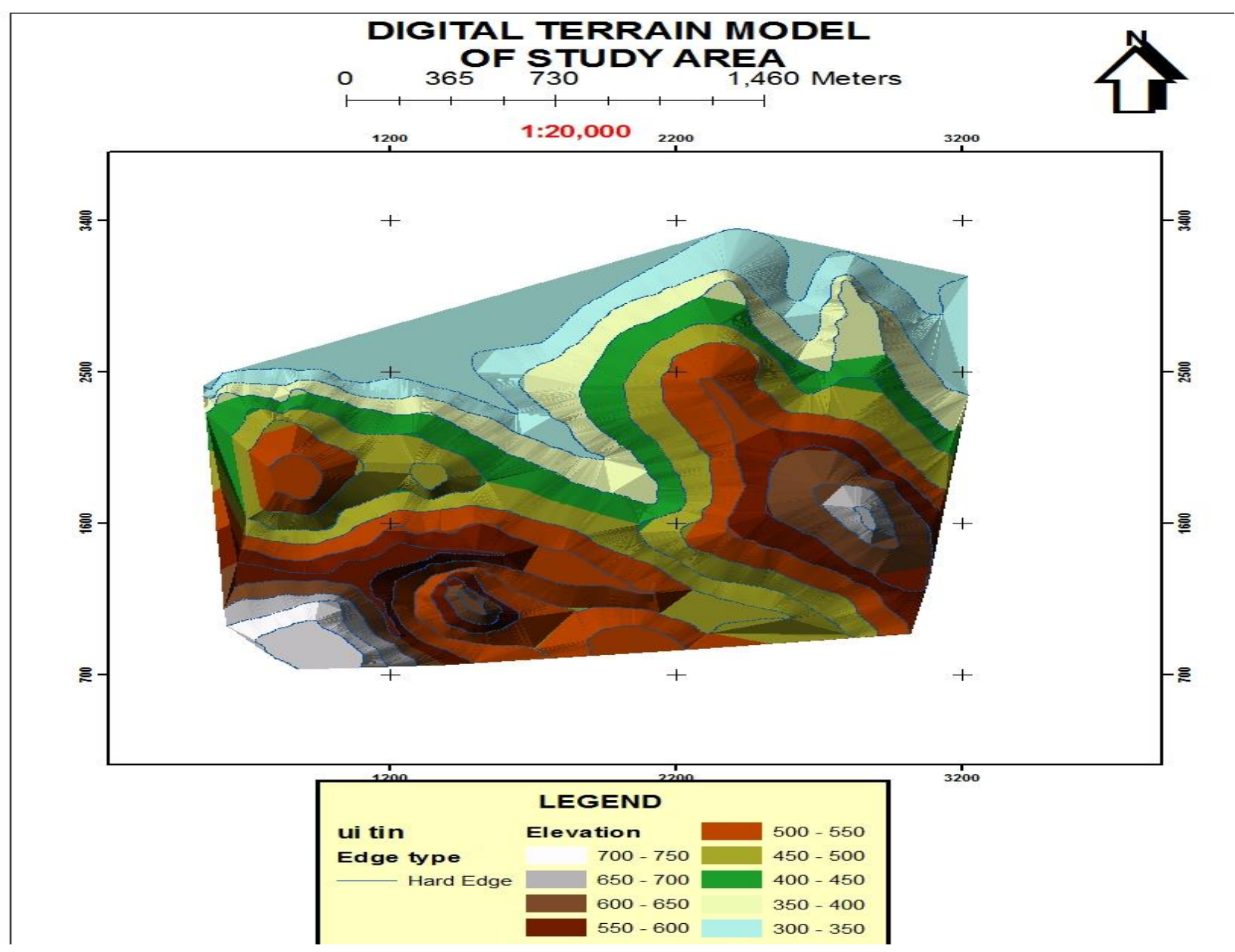

Fig. 10a Slope Map of the Study Area 


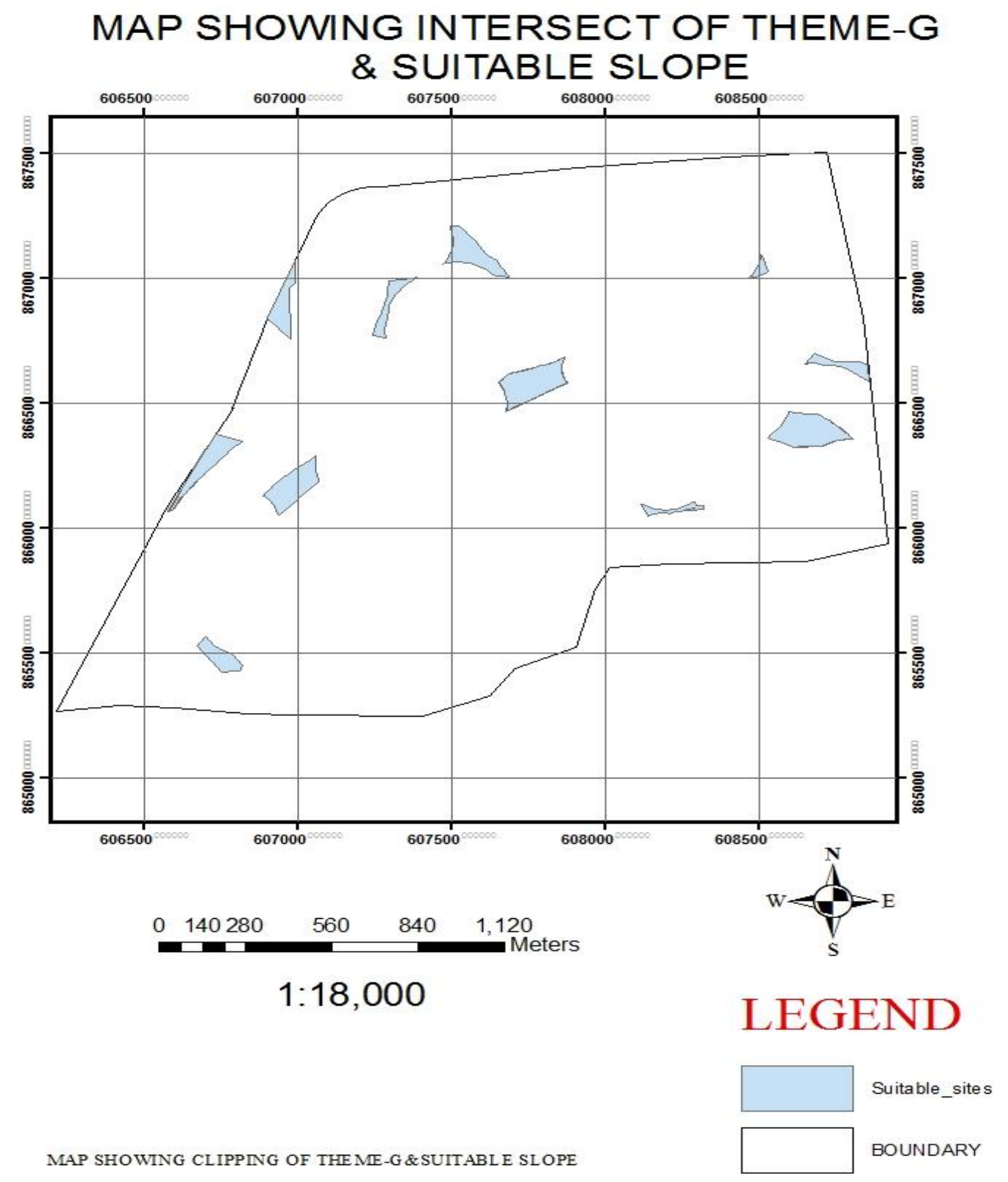

Fig. 10b: Map of the Study Area Showing Suitable Areas for Waste Landfill Sites 
The Use of Geoinformtics in Site Selection for Suitable Landfill for Poultry Waste: A Case Study of Amo Farms, AWE AFIJIO, Oyo State

\section{DATABASE EXTRACTION}

Query is one of the most common analytical functions used in GIS. This was used to select attribute data to yield the suitable sites with a size less than or equal to 2 hectares $\left(20,000 \mathrm{~m}^{2}\right)$. This query analysis generated two most suitable sites where landfill site can be sited when suitable area (S_Area2) was queried for with the stated hectares of land (greater or equal to $20,000 \mathrm{~m}^{2}$ ) as shown in figures $11 \mathrm{a}$ and $\mathrm{b}$.

\section{SYNTAX: $\quad$ S_Area2 $\geq 20,000 \mathrm{~m}^{2}$}

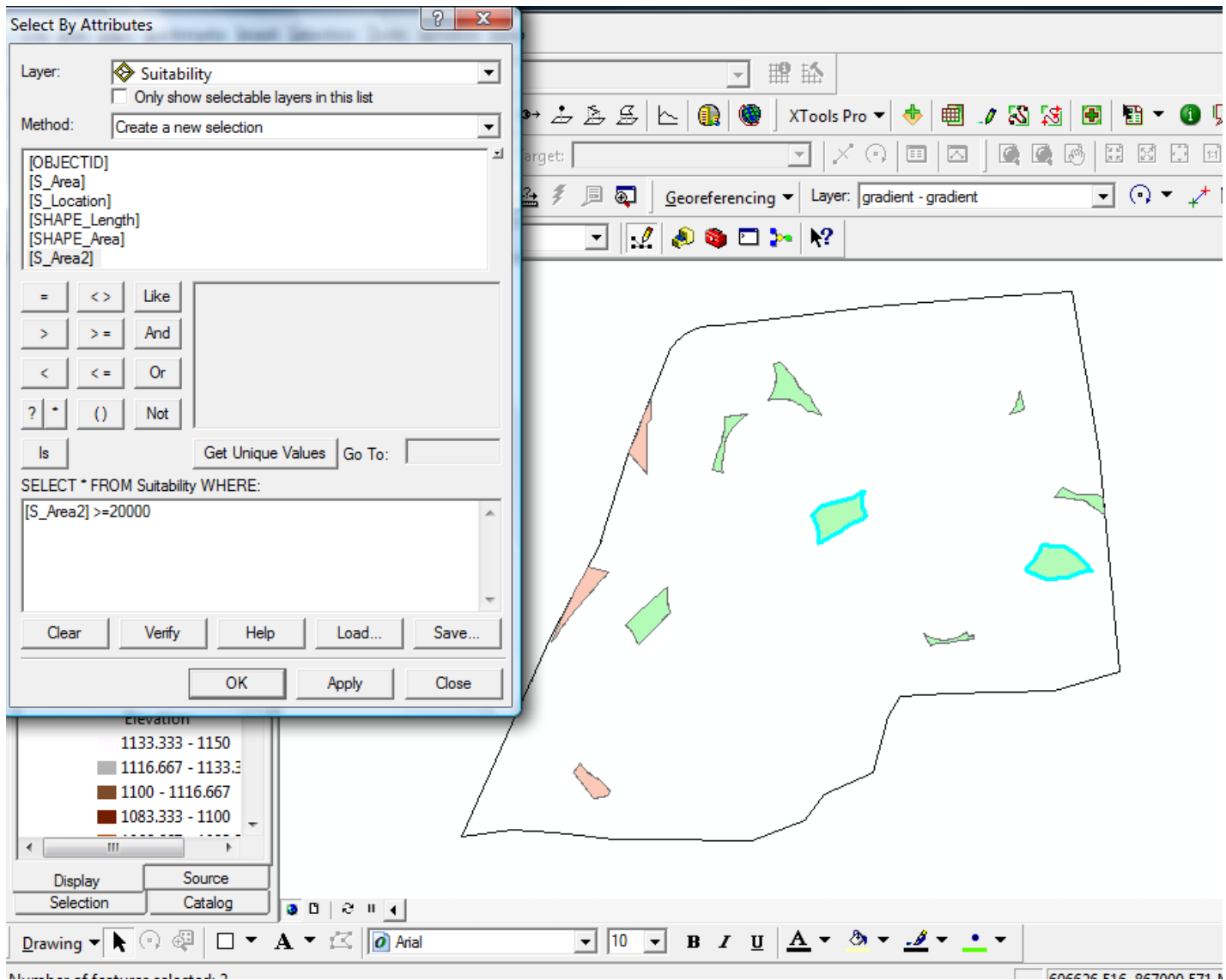

Fig. 11a: Map Layer Showing Two Most Suitable Landfill Sites 
MAP SHOWING MOST SUITABLE AREA

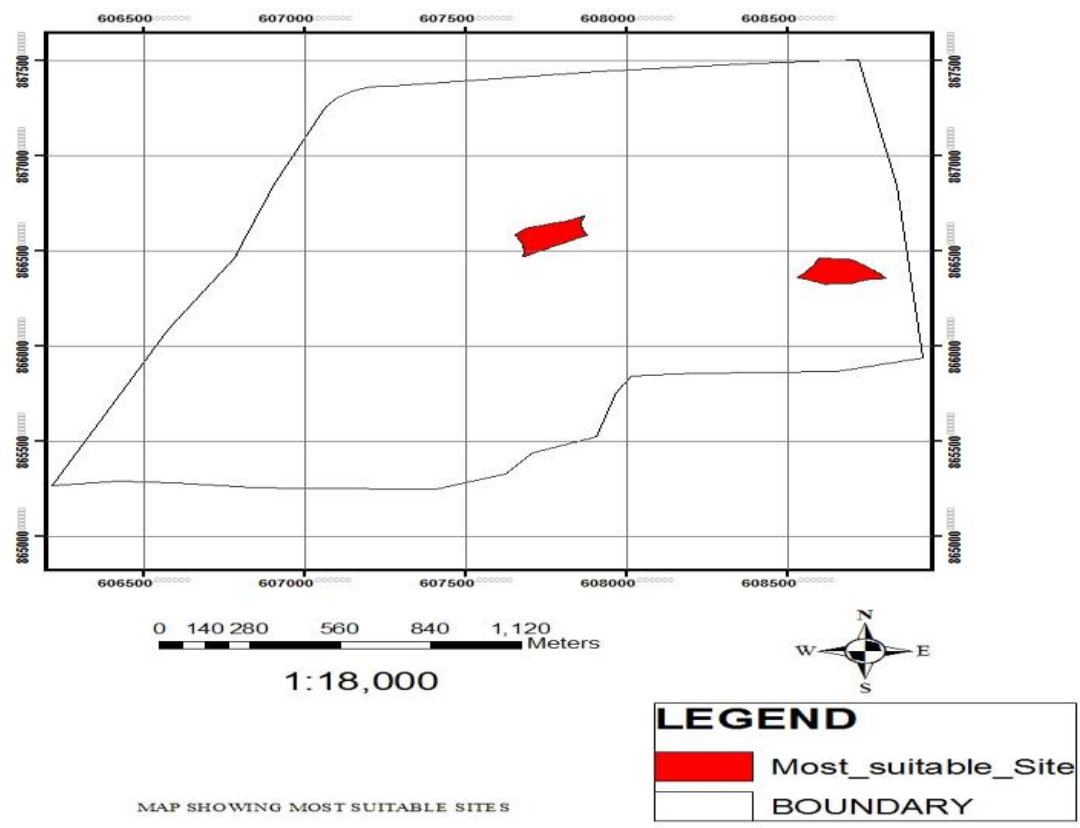

Fig. 11b: Map Layer Showing Two Most Suitable Landfill Sites

\section{DISCUSSION OF RESULTS}

The various layers used for the study were extracted from topographical map and imagery, the river and slope layers were extracted from topographical map and the other layers were extracted from the imagery and include; existing roads, water body, farm site and boundary. They were buffered to satisfy the set criteria. The Road buffer was traded off to give the boundary buffer in the first operation and the remaining portion of the area was recognized as 1 (Boundary erase_1). River buffered was also traded off with the first product (Boundary erase_1) and result was tagged 2 (Boundary erase_2), Buffered water body was also traded off to give 3 (Boundary erase_3), Buffered Farm site at the same time was also traded off to give 4(Boundary Erase_4). Products 1 and 2 were intersected to have E, E was also intersected with 3 which gave $F$ while $F$ was also intersected with 4 that resulted to $\mathrm{G}$ which was later clipped with slope of the terrain that is less than or equal to 20 degree. At the end of the analytical processes, search query was used to generate two most suitable sites of an area that is less than or equal to $20,000 \mathrm{~m}^{2}$ ( 2 hectares)

\section{REFERNCES}

1) Agunwamba J.C et al (1997) Solid Waste Management in Onitsha, Nigeria. Waste Management and Research 16(1), 23-31

2) Chain, E.S.K (1971): Sanitary Landfill Leachate and their Treatment. Journal of Environmental Engineering Division ASCE55(3), 93

3) Eastman, J. Ronald, Peter A.K. Kyem, and James Toledano. (1993). "A Procedure for Multi-Objective Decision Making in GIS under Conditions of Conflicting Objectives". Proceedings of the Fourth European Conference and Exhibition on Geographical Information Systems, EGIS '93. Genoa : EGIS Foundation, 1993. 1: 438-447

4) Mc Graw-Hill (1978): "Solid wastes and their effect on Water quality: Case study of Solid wastes and their effect on Water quality in San Francisco Bay-Delta Area" Califonia Dept.Public health,1968 - Page 304-308

5) Onosemuode C. and Dare O.T. (2010). Application of Geographical Information System (GIS) for Spatial Decision Support in Eco-Tourism Development. Environmental Research Journal 4 (2): 187-194.

6) Ukpong, E.C: "Solid Waste Management in Nigeria" Department of Civil Engineering, University of Uyo, Nigeria-International Journal of Environmental Issues Vol. 4, No 1 and 2. 2006.

7) UNEP (1996). International Source Book on Environmentally Sound Technologies for Municipal Solid Waste Management. Technical Publication Series (6), UNEP, International Environment Technology Center, Osaka/Shiga, Japan. 